\title{
Spatio-temporal variation of predator diet in a rural habitat: stone martens in the villages of Białowieża forest
}

\author{
Marta Czernik $^{1}$ - Rafal Kowalczyk ${ }^{2}$ - Andrzej Zalewski ${ }^{2}$
}

Received: 28 December 2015 / Accepted: 31 March 2016/Published online: 18 April 2016

(C) The Author(s) 2016. This article is published with open access at Springerlink.com

\begin{abstract}
The seasonal and spatial variation of the stone marten's (Martes foina) diet was studied in the villages of Białowieża Forest, north-eastern Poland. Stone marten diet varied significantly among seasons, years and villages of different size. The most important food sources were fruits and birds: 41.5 and $32.9 \%$ of consumed biomass (\% Bio), respectively. From summer to winter, fruits were the most important food, in contrast to spring, where birds dominated the diet followed by small mammals, fruits and other plant material. Fruits were eaten more frequently in the larger villages, in contrast to the smallest village, where the main food was small mammals (over $50 \%$ Bio). The contribution of different small mammal species to marten diet was dependent on the village size and habitat structure of adjacent areas. In small villages situated close to the forest, the dominant food source was forest rodents (mainly bank vole Myodes glareolus), while in the larger villages, marten hunted mainly on rats (Rattus sp.). The highest frequency of occurrence of birds in the stone marten diet was in the small village (Zwierzyniec) in summer $(67.7 \%$ Bio), while poultry consumption was the highest in the large villages (Białowieża and Podolany) in winter (over $30 \% \mathrm{Bio}$ ). The results of this study suggest that stone marten feeding habits are plastically adapted to the varying availability of different food resources in their environment. However, stone marten demonstrates high specialization to fruits, but
\end{abstract}

Communicated by: Karol Zub

Marta Czernik

czernik.marta@gmail.com

1 Institute of Biology, University of Białystok, Ciołkowskiego 1J, 15-245 Białystok, Poland

2 Mammal Research Institute, Polish Academy of Sciences, Waszkiewicza 1, 17-230 Białowieża, Poland when fruit availability is low, they supplement their diet with other components (small mammals and birds).

Keywords Food habits $\cdot$ Foraging behaviour $\cdot$ Frugivory . Key resources $\cdot$ Martes foina $\cdot$ Mustelidae

\section{Introduction}

Increasingly high rates of anthropogenic activities have rapidly replaced natural habitats with human-modified areas such as urban and rural areas (Vitousek et al. 1997; Ramankutty and Foley 1999; Goudie 2006). Many native species have disappeared from human-modified areas, but others have colonized them (Gehrt et al. 2010). To adapt to new conditions, many species have been forced to change their behaviour, morphology, and ecology (Kettlewell 1961; Diamond 1986; Ashley et al. 2003; Ditchkoff et al. 2006). In humaninfluenced areas, this has led to a complete restructuring of plant and animal communities, and of natural patterns and processes, in comparison to the natural habitats they have replaced (Brown et al. 2001; Miller and Hobbs 2002). In general, urban and rural areas are characterized by increased stability and availability of food resources for many species (Shochat et al. 2006), especially omnivorous feeders. However, the close proximity of humans and commensal species (dogs and cats) increases mortality risk and reduces access to some of these food resources. For example, the duration of animal hunting activity can be reduced by the proximity of other species (Kunz 1973). The mortality risk of animals inhabiting urban and rural habitats is increased as they are often targeted by humans to prevent them from feeding on crops (e.g. fruits) or causing damage (e.g. in poultry farming) (Naughton-Treves et al. 2003; Treves and Karanth 2003). 
Most carnivores that inhabit urban and rural habitats tend to be small or medium sized and characterized by a high reproductive potential and a wide food niche (Gehrt et al. 2010). Generally, predators select their prey or type of food based on the level of energy intake in relation to the time spent searching for and handling the prey (Stephens and Krebs 1986). Therefore, their diet composition depends on the availability of food in the environment, ability to obtain particular food types, and preferences of predators to particular types of food (Goszczyński 1986; Clode and Macdonald 1995). The availability of food in rural areas is partly associated with plant crop production and varies with the seasons and years. However, some food types in urban areas may be available all year round due to, for example, the presence of human food waste and the deliberate feeding of pets and wild animals. Furthermore, various fruits in urban and rural areas occur from the end of spring to the middle of winter, because artificially selected species or breeds of plants/trees (e.g. apple trees) may produce fruits in specific seasons, some early in summer but others late in autumn. On the other hand, food availability in rural areas is characterized by great spatial variation: there are many small patches of different food abundance (e.g. gardens with and without fruit trees). In rural habitats, variations in predator diet composition should be small between the seasons, but vary greatly between years (in relation to crop production) and among various patches or villages, in relation to the abundance of food in these patches.

The stone marten (Martes foina) is one of the species that has adapted to human-mediated environments. It inhabits the full range of residential areas, from small villages to towns and city centres (Herr 2008), but it can also be found in riparian areas, on the edges of forests, as well as in agriculture-forest mosaic areas (Sacchi and Meriggi 1995; Rondinini and Boitani 2002; Goszczyński et al. 2007; Virgos et al. 2010; Wereszczuk and Zalewski 2015). Similar to other marten species (Thompson and Colgan 1987; Zalewski and Jędrzejewski 2006), stone marten dynamics most probably relate to food availability. Stone martens are a generalist species which feed on a variety of plants and animals, but the main components of their diet are fruits, small mammals, and birds (Lode 1994; Bertolino and Dore 1995; Apathy 1998; Lanszki 2003). Stone marten diet composition varies in relation to their habitat (Romanowski and Lesiński 1991; Martinoli and Preatoni 1995; Pedrini et al. 1995; Barrientos and Virgos 2006). In both urban and rural areas, martens feed on waste left by humans; however, waste makes up a larger proportion of their diet in cities than in rural areas (Apathy 1998). In villages, their diet is more variable and dominated by fruits and mammals (Goszczyński et al. 1994; Lanszki 2003). Fruits are easy to obtain and do not require a great expenditure of energy, but they are available mainly in the summer and autumn months. Because of their high mortality in winter, rodent densities are highest in autumn and lowest in spring (Jędrzejewska and Jędrzejewski 1998); in addition, their numbers can be highly variable between years (Hanski et al. 2001; Zub et al. 2012). The diet of stone marten should be dominated by the most available food types in a particular season (e.g. birds in spring, rodents in autumn, fruits in summer and autumn) (Goszczyński 1986; Lanszki et al. 1999). The consumption of human food waste that is available year round may compensate for lower availability of other food types. Thus, the functional responses of the stone marten diet depend on the abundance of primary and secondary food types. However, the abundance of preferential and primary food resources may affect stone marten diet and dynamics (Brangi 1995; Lanszki 2003; Rodel and Stubbe 2006).

In this study, we analysed the diet of stone marten populations in villages of the Białowieża Forest, Poland. We tracked seasonal and spatial variation in stone marten diet in villages of different size and availability of the main food resources (fruits). As the species is considered a trophic generalist, we expected that seasonal change in diet composition would depend on food item availability, with fruits being the most important food item. In settlements and/or seasons where fruits were scarce, we expected stone marten to complement their diets with other components (e.g. rodents and human waste).

\section{Methods}

\section{Study area}

The study area was situated in Białowieża Forest, located on the Polish and Belarussian border $\left(52^{\circ} 30^{\prime}-53^{\circ} \mathrm{N}, 23^{\circ} 30^{\prime}-24^{\circ}\right.$ $15^{\prime} \mathrm{E}$ ). The Polish part of the forest covers $600 \mathrm{~km}^{2}$. It consists of a continuous woodlands with a few villages of different sizes inside the forest area. Open areas including human settlements, river valleys, and forest glades cover less than $7 \%$ of the area. Stone marten scats were collected from four villages: Białowieża, Podolany, Teremiski, and Zwierzyniec, located 1-7 km from one another in the central part of the forest. Białowieża is a large village with 1721 inhabitants and covers an area of 825 ha (Table 1). It has mainly wooden, closely packed residential houses, sheds, and barns. Most farms have small old orchards or individual fruit trees. The entire village is surrounded by remote forest, from 460 to $2520 \mathrm{~m}$ away in different directions. Podolany is adjacent to Białowieża, but they are separated by the Narewka River. It is the second largest village in the study area (Table 1). The settlement is characterized by dispersed development with a large number of wooden farm buildings surrounded by fruit trees. Teremiski village is located $7 \mathrm{~km}$ from Białowieża. It covers an area of 169 ha, is similar to Podolany in its development, and is surrounded by meadows and wetlands. Zwierzyniec is a small settlement located in a small mid-forest glade ( $3 \mathrm{ha}$ ) with a few wooden buildings and very few fruit trees in orchards. 
Table 1 Characteristics of the four villages in Białowieża Forest and the amounts of scat used in the analysis of stone marten (Martes foina) diet in the years 1992-2002

\begin{tabular}{lllll}
\hline Village description or season & Białowieża & Podolany & Teremiski & Zwierzyniec \\
\hline Characteristic of the village & & & & \\
Area (ha) & 825 & 344 & 169 & 3 \\
Number inhabitants ${ }^{\text {a }}$ & 1721 & 123 & 75 & 5 \\
$\quad$ Distance to the forest (m) & $460-2520$ & $720-1660$ & $480-1030$ & $60-110$ \\
Number of scats analysed & & & & 26 \\
Spring & 178 & - & - & 18 \\
Summer & 107 & 99 & 4 & - \\
Autumn & 125 & 71 & 2 & 35 \\
Winter & 103 & 35 & 24 & \\
\hline
\end{tabular}

${ }^{\mathrm{a}}$ Information from the municipal office, state of 2.06.2015
The climate is transitional, varying between continental and Atlantic types, although more continental conditions prevail (Olszewski 1986). During the study, January was the coldest month, with an average monthly temperature of $-8.5^{\circ} \mathrm{C}$ and a maximum snow cover of $55.5 \mathrm{~cm}$. The warmest month was July with an average monthly temperature of $22.5^{\circ} \mathrm{C}$.

\section{Material and methods}

From 1992 to 2002, 984 stone marten scats were collected, mostly from attics, barns and near houses. Stone marten scats were identified based on their size and shape. In contrast to other study sites, in Białowieża Forest, pine marten (Martes martes) completely avoids human settlements (Wereszczuk and Zalewski 2015); therefore, there was no uncertainty of scat identification between these species. The samples were collected in four seasons: spring - April and May, summerJune and August, autumn - September to November and winter-December to March. The number of scats collected from various sites per season is presented in Table 1. If it was not possible to ascertain from which season the scat was from, the scat was removed from the analysis. Scats were dried and stored in plastic bags until ready for analysis. The first step involved the scat being soaked in water for a few hours and then washed through a 1-mm mesh sieve (Jędrzejewska and Jędrzejewski 1998). All food remains were identified and separated using taxonomic keys (Day 1966; Pucek 1984; Brom 1986; Teerink 1991), and fruit remains were identified using a reference collection of fruits and seeds obtained from the study area. They were classified as small mammals (rodents and shrews), small birds (mainly Passeriformes, Columbiformes), poultry (Anseriformes, Galliformes), eggs, invertebrates, fruits, other plant material, or anthropogenic material. The other plant material category included grass, corn, and wood; the anthropogenic material category included both organic (wool, bones from human waste) and inorganic material (fragments of plastic, paper or fabric).
Diet composition was expressed in two ways: (1) as a percentage of occurrence (\% Occ) and (2) as a percentage of consumed biomass ( $\%$ Bio). Percentage of occurrence was defined as the proportion of scats with remains of a particular food item. To estimate biomass of different food items consumed by stone marten, weighed remains of each fraction were multiplied by the following coefficients of digestibility: small mammals - 23, eggs - 35, small birds - 35, poultry50 , other vertebrates -30 , invertebrates -5 , fruits -14 , plant material -14 , organic material -15 , and inorganic -1 (Jędrzejewska and Jędrzejewski 1998). Percentage of consumed biomass was estimated as the proportion of certain food items in the total biomass of food consumed. Because small birds and poultry had different coefficients of digestibility, birds were computed as the mean of the small birds and poultry fractions. Similarly, anthropogenic material was calculated as the mean of organic and inorganic material.

We used log-linear models to analyse the frequency of occurrence data and test for differences between seasons and locations. We used the Bonferroni correction with a significance level of 0.0026 . To examine marten diet diversity in each period, trophic niche breadth was calculated with the equation: $\mathrm{B}=1 / \Sigma \mathrm{p}_{\mathrm{i}}^{2}$, where $\mathrm{p}_{\mathrm{i}}=$ the proportion of biomass of the particular fraction. Dietary niche breadth was calculated based on the average percentage of consumed biomass of the eight groups (small mammals, birds, eggs, other vertebrates, fruits, plant material, and anthropogenic material). The seasonal variation in food niche breadths was compared using general linear models (GLM). Seasonal niche overlap was estimated using the Pianka (1973). Data analysis was performed using Statistica software (StatSoft 2011).

\section{Results}

\section{Seasonal variation in diet composition}

Overall, the stone marten diet was dominated by fruits and birds, representing 62.5 and $41.4 \%$ of intake frequency, and 
41.5 and $32.9 \%$ of consumed biomass, respectively. Small rodents constituted $12.5 \%$ of biomass consumed. Other types of food included other vertebrates $(2.4 \% \mathrm{Bio})$, anthropogenic material $(2.2 \% \mathrm{Bio})$ and invertebrates $(0.9 \% \mathrm{Bio})$. Consumption of food items varied significantly between seasons, and diet composition during spring was significantly different from the other three seasons (Tables 2 and 3). In spring, martens consumed higher amounts of small mammals, birds and invertebrates, while fruits dominated their diets in other seasons (Table 2). Of the small mammals, stone martens preyed mainly on rats (Rattus spp.), especially during spring (Table 2). The predation of Microtus voles was highest in autumn. Other species of rodents (house mice Mus musculus, Apodemus mice and bank voles Clethrionomys glareolus) made only small contributions to the marten diet. Birds (mainly passerine birds) constituted a dominant component of marten diet throughout year though they had a slightly lower contribution to the diet in winter (Table 2). However, the contribution of poultry to the marten diet increased in winter (Table 2, Fig. 1). Invertebrates were often consumed (they occurred in $22-40 \%$ of scats) (Table 2); however, their biomass was low. Of the invertebrates consumed, martens mainly preyed upon Coleoptera species and Hymenoptera in the summer. Fruits proved to be the most important food source from summer to winter (66-76\% of occurrence) (Table 2). Fruit consumption was comprised mainly of pears (Pyrus spp.) and cherries (Cerasus spp.) in summer, plums (Prunus domestica)

Table 2 Seasonal variation in stone marten (Martes foina) diet in the years 1992-2002 in villages of Białowieża Forest

\begin{tabular}{lllll}
\hline Prey item & Spring & Summer & Autumn & Winter \\
\hline Rat Rattus spp. & 20.1 & 6.6 & 3.0 & 4.6 \\
House mouse Mus musculus & 3.2 & 1.7 & 2.6 & 3.0 \\
Microtus voles & 1.9 & 3.5 & 5.6 & 2.2 \\
Small mammals & 48.0 & 28.5 & 24.2 & 30.5 \\
Small birds & 39.2 & 34.2 & 27.8 & 14.7 \\
Poultry & 10.8 & 11.0 & 11.1 & 16.8 \\
Birds & 50.0 & 44.3 & 38.9 & 31.5 \\
Eggs & 22.5 & 13.2 & 14.1 & 8.6 \\
Coleoptera & 20.6 & 10.1 & 10.6 & 9.6 \\
Invertebrates & 40.2 & 24.1 & 26.8 & 22.3 \\
Pear Pyrus spp. & 11.3 & 34.6 & 16.2 & 13.2 \\
Plums Prunus domestica & 6.9 & 8.3 & 30.3 & 6.1 \\
Apples Malus spp. & 2.0 & 3.9 & 3.5 & 16.2 \\
Currants Ribes spp. & 0.5 & 12.3 & 20.2 & 29.4 \\
Cherries Cerasus spp. & 0.5 & 11.8 & 5.1 & 3.6 \\
Fruits & 35.8 & 66.7 & 75.8 & 72.1 \\
Other plant material & 57.8 & 28.5 & 26.8 & 26.4 \\
Anthropogenic material & 16.7 & 4.8 & 7.1 & 12.2 \\
\hline
\end{tabular}

Diet composition was calculated as the percentage of occurrence $(\% \mathrm{Occ})$
Table 3 Summary of the log-linear analyses of variation in stone marten diet composition in different seasons and villages in Białowieża Forest

\begin{tabular}{|c|c|c|c|c|}
\hline Food item & Effect & $d f$ & $\chi^{2}$ & $p$ \\
\hline \multirow[t]{3}{*}{ Rattus spp. } & Season & 3 & 39.85 & $<0.0001$ \\
\hline & Location & 3 & 3.29 & 0.35 \\
\hline & Season $\times$ location & 9 & 13.55 & 0.14 \\
\hline \multirow[t]{3}{*}{ Small mammals } & Season & 3 & 37.03 & $<0.0001$ \\
\hline & Location & 3 & 52.48 & $<0.0001$ \\
\hline & Season $\times$ location & 9 & 29.57 & 0.001 \\
\hline \multirow[t]{3}{*}{ Small birds } & Season & 3 & 25.58 & $<0.0001$ \\
\hline & Location & 3 & 9.53 & 0.023 \\
\hline & Season $\times$ location & 9 & 16.39 & 0.059 \\
\hline \multirow[t]{3}{*}{ Poultry } & Season & 3 & 5.83 & 0.12 \\
\hline & Location & 3 & 5.28 & 0.15 \\
\hline & Season $\times$ location & 9 & 39.31 & $<0.0001$ \\
\hline \multirow[t]{3}{*}{ Birds } & Season & 3 & 8.24 & 0.041 \\
\hline & Location & 3 & 26.89 & $<0.0001$ \\
\hline & Season $\times$ location & 9 & 41.40 & $<0.0001$ \\
\hline \multirow[t]{3}{*}{ Eggs } & Season & 3 & 16.99 & 0.0007 \\
\hline & Location & 3 & 9.30 & 0.026 \\
\hline & Season $\times$ location & 9 & 20.12 & 0.017 \\
\hline \multirow[t]{3}{*}{ Invertebrates } & Season & 3 & 15.11 & 0.0017 \\
\hline & Location & 3 & 27.71 & $<0.0001$ \\
\hline & Season $\times$ location & 9 & 30.68 & 0.0003 \\
\hline \multirow[t]{3}{*}{ Pyrus spp. } & Season & 3 & 72.47 & $<0.0001$ \\
\hline & Location & 3 & 82.88 & $<0.0001$ \\
\hline & Season $\times$ location & 9 & 29.68 & 0.0005 \\
\hline \multirow[t]{3}{*}{ Prunus domestica } & Season & 3 & 52.68 & $<0.0001$ \\
\hline & Location & 3 & 3.89 & 0.27 \\
\hline & Season $\times$ location & 9 & 24.45 & 0.0036 \\
\hline \multirow[t]{3}{*}{ Malus spp. } & Season & 3 & 15.59 & 0.0014 \\
\hline & Location & 3 & 31.14 & $<0.0001$ \\
\hline & Season $\times$ location & 9 & 8.62 & 0.47 \\
\hline \multirow[t]{3}{*}{ Ribes spp. } & Season & 3 & 96.61 & $<0.0001$ \\
\hline & Location & 3 & 35.10 & $<0.0001$ \\
\hline & Season $\times$ location & 9 & 67.99 & $<0.0001$ \\
\hline \multirow[t]{3}{*}{ Cerasus spp. } & Season & 3 & 7.91 & 0.048 \\
\hline & Location & 3 & 27.05 & $<0.0001$ \\
\hline & Season $\times$ location & 9 & 25.76 & 0.0022 \\
\hline \multirow[t]{3}{*}{ Fruits } & Season & 3 & 73.29 & $<0.0001$ \\
\hline & Location & 3 & 81.61 & $<0.0001$ \\
\hline & Season $\times$ location & 9 & 20.90 & 0.013 \\
\hline \multirow[t]{3}{*}{ Other plant material } & Season & 3 & 73.26 & $<0.0001$ \\
\hline & Location & 3 & 170.71 & $<0.0001$ \\
\hline & Season $\times$ location & 9 & 32.03 & 0.00019 \\
\hline \multirow[t]{3}{*}{ Anthropogenic material } & Season & 3 & 14.21 & 0.00264 \\
\hline & Location & 3 & 29.40 & $<0.0001$ \\
\hline & Season $\times$ location & 9 & 13.36 & 0.15 \\
\hline
\end{tabular}

Numbers in italics indicate significant values after Bonferroni correction 
in autumn, and currants (Ribes spp.) and apples (Malus spp.) in winter.

Seasonal contributions to the percentages of consumed biomass also appeared to vary in a similar pattern (Fig. 1). The composition of the marten diet in spring again differed to other seasons. In spring, the diet was dominated by birds, with approximately equal proportions of small mammals, fruits, and other plant material consumed (Fig. 1). From summer to winter, dietary composition was dominated by fruits (45 to $55 \%$ Bio), followed by birds, and the smallest contribution was by small mammals (28 to $33 \%$ Bio for birds, 8 to $15 \%$ Bio for small mammals).

The breadth of the food niche was highest during spring (3.98) and lowest during autumn (2.57) when the marten's diet was dominated by fruits. In the two other seasons (summer and winter), food niche breadth was similar (Fig. 1). The overall GLM for the seasonal food niche breadth value was not significant $(F=2.22, p=0.27)$. Seasonal niche overlap was highest between summer-autumn and summer-winter (0.99 for both comparisons) and was lowest for spring-autumn (0.74).

\section{Spatial variability of diet}

The composition of the stone marten diet varied significantly between villages (Table 3, Fig. 2). Fruits were eaten more often in the larger villages (Białowieża and Podolany) than in the smallest village (Zwierzyniec). There was also variation between villages in the fruit species consumed by martens. In Białowieża and Teremiski, pears and currants were eaten most often, whereas in Podolany it was cherries, and in Zwierzyniec strawberries. In contrast to fruit consumption, the proportion of small mammals in the stone marten diet showed the opposite trend. In all seasons, small mammals were the most abundant marten diet component in the smaller village (over $50 \%$ in Zwierzyniec), in contrast to the larger villages, especially Białowieża, where the proportion of small mammals was lowest from summer to winter (Fig. 2). In relation to village size, there were also differences in the rodent species in the marten diet. In the smaller villages, martens preyed upon forest rodents (Apodemus mice, bank vole) and the Microtus vole, whereas in the large villages martens preyed mostly on rats. The proportion of birds as a dietary component also differed significantly between villages. Overall, martens consumed the highest frequency of birds in the smallest village (up to $72 \%$ of consumed biomass in Zwierzyniec). In Białowieża, the proportion of birds in the marten diet also remained relatively high, especially in spring. Consumption of hens was highest during winter in larger villages (Białowieża-36\% and Podolany-41\% of consumed biomass), and domestic ducks were consumed solely during the summer in Teremiski (56\% of consumed biomass). In comparison to other villages, invertebrates were eaten more frequently in Zwierzyniec during spring and winter; however, overall biomass of this prey in the marten's diet was generally low (Fig. 2).

\section{Between-year variation in diet composition}

The dietary composition of stone marten greatly varied between years, especially in the proportions of fruits, small mammals, and birds consumed (Fig. 3). Martens consumed more fruits in 1995 and 2000 (up to $70 \%$ of consumed biomass). In 1998, fruit consumption decreased to only $18 \%$ of biomass consumed. The lower proportion of fruits in the marten's diet was supplemented by other prey items: small
Fig. 1 Seasonal variation in diet composition ( $\%$ of consumed biomass) of stone martens (Martes foina) in villages of Białowieża Forest in 1992-2002. Numbers above the bars indicate food niche breadth values

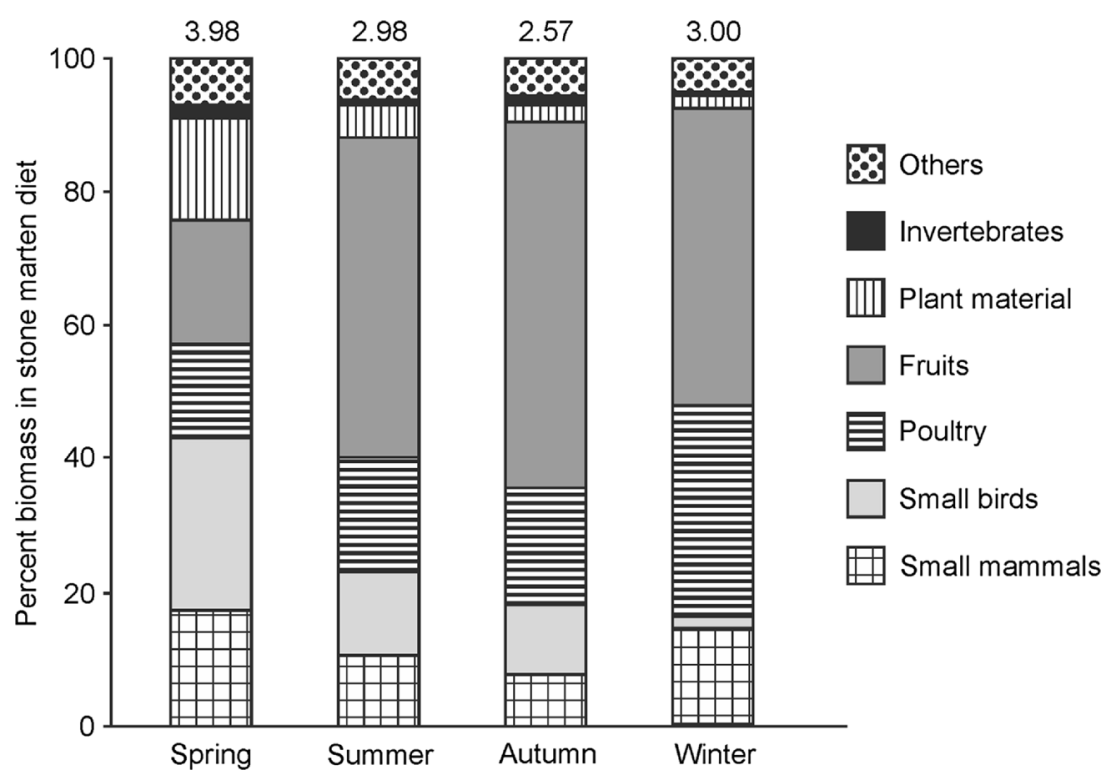




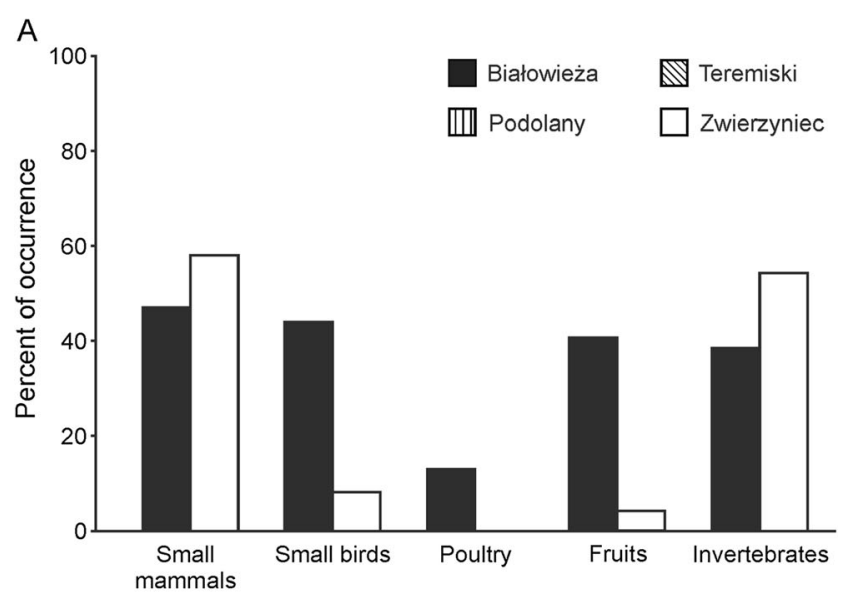

B
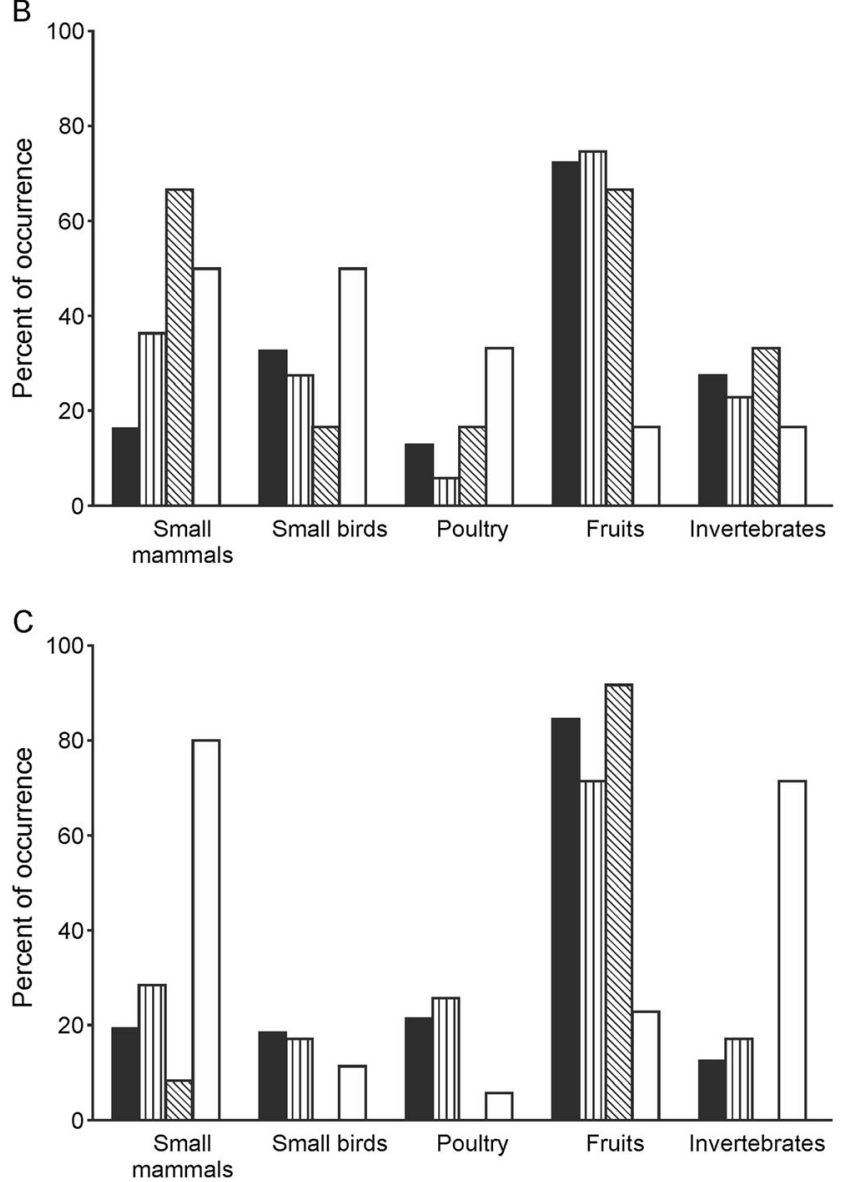

Fig. 2 Spring a summer-autumn $\mathbf{b}$ and winter $\mathbf{c}$ variation in diet composition (\% of occurrence) of stone martens in villages of Białowieża Forest in 1992-2002. In spring, scats were not collected in Podolany and Teremiski

mammals and birds (both small passerines as well as poultry; Fig. 3). In 1998, the proportion of small mammals and birds in consumed biomass increased to 35 and $32 \%$, respectively. A similar high proportion of small mammals was recorded in 1999 (26 \% Bio). In other years, the contribution of small mammals to consumed biomass varied only between 0 and $13 \%$ (Fig. 3).

\section{Discussion}

Our results showed the opportunistic feeding habits of stone martens in villages within the Białowieża Forest and the wide variety of food types that form their diet, from mammals, birds, and insects to fruits and human waste. Stone marten hunted on wild species (rodents or passerine birds), preyed upon domestic species (domestic hens and ducks), and fed in orchards on fruits. The marten's dietary composition varied seasonally, between years and in relation to village size. Many other generalist predators have shown a similar spatial and temporal flexibility of dietary composition and plasticity, in their capacity to adapt to changing abundances of food resources within the environment (Jędrzejewski and Jẹdrzejewska 1992; Lanszki et al. 1999, 2007; Borkowski et al. 2011; Kidawa and Kowalczyk 2011). Seasonal and inter-annual variation in dietary composition has also been observed in other martens. Pine marten, sable (Martes zibellina) and American marten (Martes americana) diets have been shown to be primarily dependent on the abundance of rodents (Thompson and Colgan 1990; Jędrzejewski et al. 1993; Helldin 1999; Zalewski 2004, 2007; Lanszki et al. 2007; Dubinin 2010; Balestrieri et al. 2011). In seasons, or years when abundance of their main prey is low, these marten species supplement their diet with other food sources, e.g. birds, shrews, fruits or carcasses of ungulates (Jeedrzejewski et al. 1993; Lanszki et al. 1999, 2007; Zalewski 2004). The population densities and dynamics of these marten species have been related to rodent abundance (Thompson and Colgan 1987; Zalewski and Jędrzejewski 2006). In contrast, stone marten diet has been shown to be mainly dominated by fruits (Brangi 1995; Lanszki 2003; Rodel and Stubbe 2006; Posłuszny et al. 2007; Bakaloudis et al. 2012). In our study, lower abundance of this food type was compensated for by supplementary food items (rodents and birds), both spatially and temporally. Spatial and temporal variation in fruit availability may shape stone marten distribution patterns and potentially their population dynamics (Virgos et al. 2010).

Generally, the proportion of fruit in the stone marten diet varies on a latitudinal gradient, with higher proportions of fruit consumed in southern Europe (Pandolfi et al. 1996); this is related to higher abundances of plant species which produce edible fruits in this region (Padial et al. 2002; Lanszki 2003; Barrientos and Virgos 2006). In Central Europe, in the villages of the Białowieża Forest, fruits (mainly apples, currants and pears) also constituted the most important stone marten food, in all seasons. The consumption of various types of fruits was associated with the order of their seasonal appearance. In summer, martens consumed pears, strawberries (Fragaria spp.) and cherries. In autumn, they consumed plums, currants and apples. Fruit consumption associated with temporal appearance was similarly observed in other studies (Serafini and Lovari 1993; Bertolino and Dore 1995; Posillico et al. 1995; 
Fig. 3 Between-year variation in stone marten (Martes foina) diet in Białowieża Forest in summer, autumn, and winter. Numbers indicate scat sample size in each year

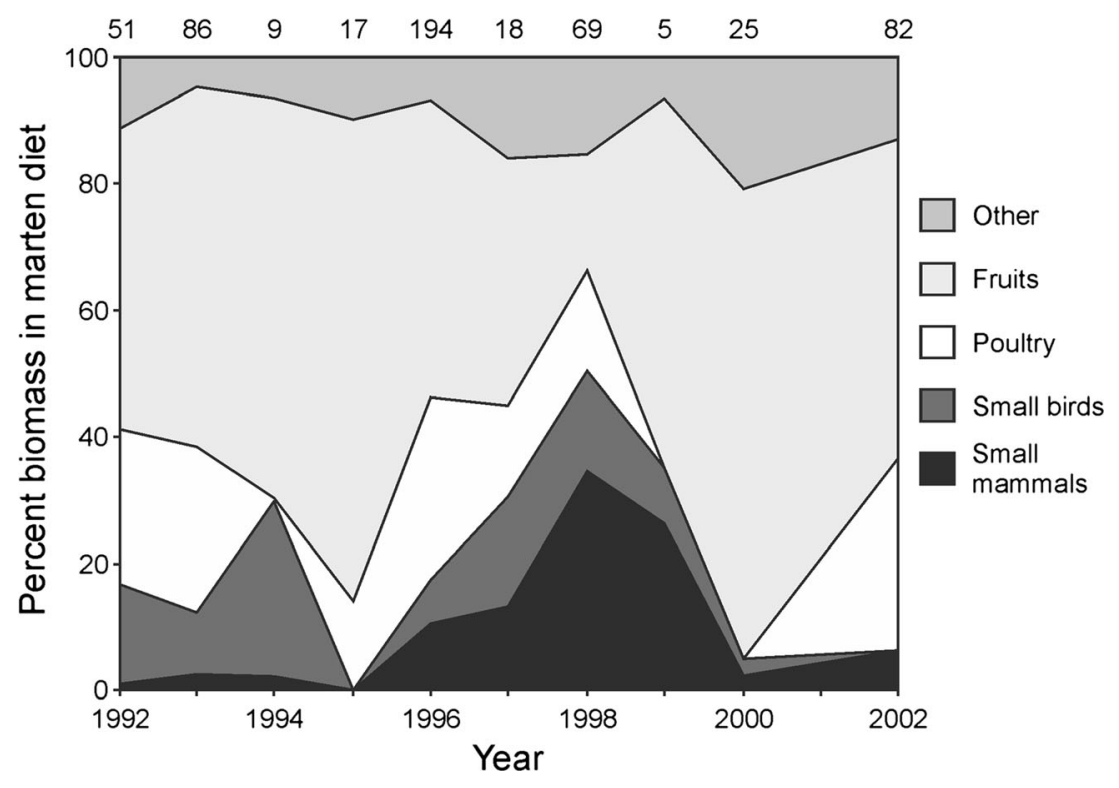

Rodel and Stubbe 2006; Georgiev 2013); this shows flexibility in food habits in relation to the abundance of various fruits. The occurrence of fruits in stone marten diets in winter and spring, when fruits are generally not produced, is a result of their availability in the villages of the Białowieża Forest. Village residents often do not collect fruits, such as apples, from the trees. These fruits then drop to the ground later in autumn and winter and are preserved by the cold weather. Currants that are not harvested may hang on bushes until late winter (M. Czernik personal observation) and therefore can be a food source for martens. Currants have been found in the stomachs of stone martens in spring (Ruprecht and Buszko 1985). Snow tracking of stone martens in winter showed digging behaviour in the snow that could be associated with a search for apples (A. Zalewski personal observation). Fruits can also be consumed by martens from compost sites as the practice of utilizing organic waste for making compost is very common in the area. Village residents use compost sites to dispose of whole or parts of fruits as well as household fruit preserves (compotes, jams or wine). Monitoring of compost sites using camera-traps revealed that martens use these sites regularly throughout the year (A. Wereszczuk unpublished data).

Compost sites, as well as landfill sites could also be sources of anthropogenic food items for martens. Various types of these food items were found in marten scats: organic (human food leftovers such as pork, beef or rabbit) and inorganic materials (such as aluminium foil, plastic, net, paper, glass, fabric, wool) that were probably consumed accidentally with edible parts of food. Anthropogenic food was often found in marten diet during the spring and winter, and its contribution to total biomass consumed was especially high in the smaller village of Zwierzyniec (up to $23 \%$ in the spring). This suggests that organic anthropogenic food was especially important during periods, or at sites where fruits were less accessible. However, this component may be underestimated based on scat analyses because a large portion of the anthropogenic food consumed by martens could be completely digested and would not appear in scats. In many studies of stone marten diet, this type of food has not been reported (Carvalho and Gomes 2004; Lode 1994), but generally in villages, the proportion of anthropogenic food consumption is higher than in farmlands (Romanowski and Lesiński 1991) and lower than in cities (Apathy 1998). This may be associated with the availability of human waste within the different habitat types.

Birds were an alternative source of prey for stone martens and were divided into two categories: wild and domestic birds. Small wild birds, mainly passerines, were consumed at higher proportions in spring (especially in Białowieża) and summer (in the other villages). This can be related to areas of woodlots, such as parks in Białowieża, which increase bird accessibility within the village. In spring and summer, the proportion of bird eggs in the marten diet also increased. This is most likely due to the greater abundance of eggs during these seasons. Similarly, in other regions of Europe, a higher proportion of bird consumption was observed in the stone marten diet during spring (Pedrini et al. 1995; Carvalho and Gomes 2004; Barrientos and Virgos 2006); at some sites, more than half of the consumed biomass was composed of passerines (Romanowski and Lesiński 1991; Serafini and Lovari 1993). However, in some regions, bird contribution to marten diet was highest in winter (Serafini and Lovari 1993; Bertolino and Dore 1995; Posillico et al. 1995; Georgiev 2013), though the proportion of wild and domestic birds was often not distinguished in these studies. The percentage of poultry biomass consumed in our study increased from $17 \%$ in spring-autumn to $32 \%$ in winter. Poultry, especially domestic hens, were an 
important food source especially in larger villages like Białowieża and Podolany. In winter, larger prey (like domestic hens), as they reduce their activity due to the decreasing ambient temperature, are very important to mustelids (Zalewski 2000, 2001; Zalewski et al. 2004). However, domestic animal predation often leads to human-predator conflicts.

The second most important supplement to the marten diet was small mammals, especially rodents. In the villages of Białowieża Forest, the contribution of rodents to marten diet was highest in the spring, although their abundance in villages is lowest at this time of year due to their high winter mortality (Jędrzejewska and Jędrzejewski 1998; Wijnhoven et al. 2005). Similarly, at other sites, the contribution of rodents to marten diet dominated in spring and reached up to $70 \%$ of consumed biomass at some sites (Martinoli and Preatoni 1995; Barrientos and Virgos 2006). At other sites, mammals dominated marten diet during the winter (Carvalho and Gomes 2004; Lode 1994). Cumulatively, this indicates that marten predation on rodents is probably not dependent on their seasonal availability but is related to the availability of their main food item-fruit (Romanowski and Lesiński 1991; Brangi 1995)

In the larger villages (Białowieża and Podolany), the most important rodent species were rats, whereas the consumption of other rodents (house mice, Microtus voles and Apodemus mice) was rare. In the diet of the tawny owl (Strix aluco) inhabiting Białowieża, which was studied during the same period, Microtus voles dominated, while rats were eaten only sporadically (2.9\%; Gryz et al. 2012). This may relate to differential hunting microhabitat selection by these predators (barns and stables by stone marten and open areas by tawny owls), but it also may indicate that stone marten prefer rats over other species of the rodent community inhabiting the village. Interestingly, in Portugal rats were not preyed upon by stone marten despite the fact that the red fox (Vulpes vulpes) and the Egyptian mongoose (Herpestes ichneumon) consumed rats frequently (Santos et al. 2007). In other regions, rats were also consumed in small proportions (Lode 1994; Lanszki 2003) or were not found at all in the stone marten diet (Serafini and Lovari 1993; Martinoli and Preatoni 1995; Pedrini et al. 1995; Carvalho and Gomes 2004; Barrientos and Virgos 2006). The composition of rodent species in the marten diet was related to village size. The contribution of forest rodents (bank vole and yellow neck mice Apodemus flavicollis) was highest in the small village located in close proximity to, and surrounded by the forest (Zwierzyniec). In other studies, Microtus voles or house mice dominated stone marten diets in villages (Lode 1994; Lanszki 2003), whereas the diets of stone martens inhabiting rural areas were dominated by bank voles (Goszczyński 1986; Bertolino and Dore 1995), common voles (Microtus arvalis)
(Goszczyński 1976; Romanowski and Lesiński 1991; Lode 1994; Lanszki et al. 1999) or Apodemus mice (Serafini and Lovari 1993; Barrientos and Virgos 2006). In cities (e.g. Budapest), mainly wood mice (Apodemus sylvaticus) and house mice dominated their diet (Apathy 1998). In Białowieża Forest, a high proportion of rodents associate with human settlements in stone marten diet are related to marten habitat selection. In these large forest complexes, stone marten was found to avoid forest habitats and strongly prefer villages as hunting areas (Wereszczuk and Zalewski 2015).

Comparisons of stone and pine marten diets in Białowieża Forest suggest that both species feed on a wide variety of prey. Stone marten, however, consumes greater amounts of fruit and human-related food items (poultry, human waste). In contrast, pine marten consumes greater amounts of rodents (primarily bank voles) and supplements their diets with birds and fruits during spring and summer, and shrews and ungulate carrion in autumn and winter (Jędrzejewski et al. 1993; Zalewski 2007). Only in the smaller village, located in close proximity to the forest, where the diets of both stone and pine marten were similar. The dietary differences of these two marten species are related to differences in habitat selection: while stone martens prefer anthropogenic habitats (generally developed areas), pine marten prefers forested areas (Wereszczuk and Zalewski 2015). This spatial niche segregation reduces competition for food, allowing coexistence of both species within the Białowieża Forest area.

This study showed that fruits were the primary component of stone marten diet. Stone marten demonstrated high specialization to fruit and high plasticity to the varying availability of other food resources. The stone marten diet was more similar between seasons than between sites and years, which varied greatly. At sites where fruits are scarce (small villages), martens supplement their diet mainly with birds (including poultry) and rodents. Wild birds were preyed upon during periods of their high abundance, in contrast to rodents which were often preyed upon during seasons of their low abundance (spring). This supports the hypothesis that fruit availability drives the dietary composition of stone martens. The advantage for stone martens adapting to living in villages is a high and complementary food supply which is reliable throughout the year (including poultry); this may result in high and relatively stable population numbers. However, stone marten predation on domestic animals leads to human-marten conflict, which may result in martens being targeted by humans and potentially high mortality rates which may affect their dynamics.

Acknowledgments The authors are grateful to E. Bujko for his help with field work. We thank K. Grzebyk and A. L. O'Brien for help in correcting the English and two anonymous reviewers for insightful comments on an earlier version of the manuscript. 
The study was financed by the budget of the Mammal Research Institute PAS and the University of Białystok (BST-102).

\section{Compliance with ethical standards}

Conflict of interest The authors declare that they have no conflict of interest.

Open Access This article is distributed under the terms of the Creative Commons Attribution 4.0 International License (http:// creativecommons.org/licenses/by/4.0/), which permits unrestricted use, distribution, and reproduction in any medium, provided you give appropriate credit to the original author(s) and the source, provide a link to the Creative Commons license, and indicate if changes were made.

\section{References}

Apathy MT (1998) Data to the diet of the urban Stone marten (Martes foina Erxleben) in Budapest. Opusc Zool Budapest 31:113-118

Ashley MV, Willson MF, Pergams ORW, O'Dowd DJ, Gende SM, Brown JS (2003) Evolutionarily enlightened management. Biol Cons 111:115-123

Bakaloudis D, Vlach CG, Papakosta MA, Bontzorlos V, Chatzinikos EN (2012) Diet composition and feeding strategies of the stone marten (Martes foina) in a typical Mediterranean ecosystem. The Scientific World Jo, 163920. DOI 10.1100/2012/163920

Balestrieri A, Remonti L, Ruiz-González A, Vergara M, Capelli E, Gómez-Moliner BJ, Prigioni C (2011) Food habits of genetically identified pine marten (Martes martes) expanding in agricultural lowlands (NW Italy). Acta Theriol 56:199-207. doi:10.1007/ s13364-010-0015-8

Barrientos R, Virgos E (2006) Reduction of potential food interference in two sympatric carnivores by sequential use of shared resources. Acta Oecol 30:107-116. doi:10.1016/j.actao.2006.02.006

Bertolino S, Dore B (1995) Food habits of the stone marten Martes foina in „La Mandria” Regional Park (Piedmont Region, north-western Italy). Hystrix 7:105-111

Borkowski K, Zalewski A, Manor R (2011) Diet composition of golden jackals in Israel. Ann Zool Fenn 48:108-118

Brangi A (1995) Seasonal changes of trophic niche overlap in the stone marten (Martes foina) and the red fox (Vulpes vulpes) in a mountainous area of the Northern Apennines (N-Italy). Hystrix 7:113-118

Brom TG (1986) Microscopic identification of feathers and feather fragments of palearctic birds. Bijdr tot de Dierkd 56:181-204

Brown JH, Whitham TG, Ernest SKM, Gehring CA (2001) Complex species interactions and the dynamics of ecological systems: longterm experiments. Science 293:643-650

Carvalho JC, Gomes P (2004) Feeding resource partitioning among four sympatric carnivores in the Peneda-Geres National Park (Portugal). J Zool 263:275-283. doi:10.1017/S0952836904005266

Clode D, Macdonald DW (1995) Evidence for food composition between mink (Mustela vison) and otter (Lutra lutra) on Scottish island. J Zool 237:435-444

Day MG (1966) Identification of hair and feather remains in the gut and faeces of stoats and weasels. J Zool 148:201-217

Diamond JM (1986) Rapid evolution of urban birds. Nature 324:107-108

Ditchkoff SS, Saalfeld ST, Gibson CJ (2006) Animal behavior in urban ecosystems: modifications due to human-induced stress. Urban Ecosyst 9:5-12. doi:10.1007/s11252-006-3262-3
Dubinin EA (2010) On sexual dimorphism in the winter diet of the sable (Martes zibellina L.). Russ J Ecol 41:244-248. doi:10.1134/ S1067413610030082

Gehrt SD, Riley SPD, Cypher BL (2010) Urban Carnivores: ecology, conflict, and conservation. John Hopkins University Press, Baltimore

Georgiev D (2013) Diet of the Stone marten (Martes foina Erxl.) in two large cities of the Upper Thracian Lowland, South Bulgaria. ZooNotes 42:1-4

Goszczyński J (1976) Composition of the food of martens. Acta Theriol 21:527-534

Goszczyński J (1986) Diet of foxes and martens in Central Poland. Acta Theriol 36:491-506

Goszczyński J, Romanowski J, Zalewski A (1994) Kuny. Oficyna Edytorska Wydawnictwo Świat, Warszawa

Goszczyński J, Posłuszny M, Pilot M, Gralak B (2007) Patterns of winter locomotion and foraging in two sympatric marten species: Martes martes and Martes foina. Can J Zool 85:239-249. doi:10.1139/Z06212

Goudie A (2006) The human impact on the natural environment: past, present and future, 6th edn. Blackwell Publishing, Oxford

Gryz J, Lesiński G, Kowalski M, Krauze D (2012) Food composition of tawny owl Strix aluco in Białowieża Primeval Forest. Chrońmy Przyr Ojczysta 68:100-108

Hanski I, Henttonen H, Korpimaki E, Oksanen L, Turchin P (2001) Small-rodent dynamics and predation. Ecology 82:1505-1520

Helldin JO (1999) Diet, body condition, and reproduction of Eurasian pine martens Martes martes during cycles in microtine density. Ecography 22:324-336

Herr, J (2008) Ecology and behavior of urban stone martens (Martes foina) in Luxembourg. PhD Thesis, University of Sussex

Jędrzejewska B, Jędrzejewski W (1998) Predation in vertebrate communities. The Białowieża Primeval Forest as a case study. Springer, Berlin, Heidelberg, New York

Jędrzejewski W, Jędrzejewska B (1992) Foraging and diet of the red fox Vulpes vulpes in relation to variable food resource in Białowieża National Park, Poland. Ecography 15:212-220

Jędrzejewski W, Zalewski A, Jędrzejewska B (1993) Foraging by pine marten Martes martes in relation to food resources in Białowieża National Park, Poland. Acta Theriol 38:405-426

Kettlewell HBD (1961) The phenomenon of industrial melanism in Lepidoptera. Annu Rev Entomol 6:245-262

Kidawa D, Kowalczyk R (2011) The effects of sex, age, season and habitat on diet of the red fox Vulpes vulpes in northeastern Poland. Acta Theriol 56:209-218

Kunz TH (1973) Resource utilization: temporal and spatial components of bat activity in central Iowa. J Mamm 54:14-32. doi:10.2307/ 1378869

Lanszki J, Kormendi S, Hancz C, Zalewski A (1999) Feeding habits and trophic niche overlap in a Carnivora community of Hungary. Acta Theriol 44:492-442

Lanszki J (2003) Feeding habits of stone martens in a Hungarian village and its surroundings. Folia Zool 52:367-377

Lanszki J, Zalewski A, Horvath G (2007) Comparison of red fox Vulpes vulpes and pine marten Martes martes food habits in a deciduous forest in Hungary. Wildl Biol 13:258-271. DOI http://dx.doi.org/ 10.2981/0909-6396(2007)13[258:CORFVV]2.0.CO;2

Lode TH (1994) Feeding habits of the Stone marten Martes foina and environmental factors in western France. Z Säugetierkd 59:189-191

Martinoli A, Preatoni DG (1995) Food habits of the stone marten (Martes foina) in the Upper Aveto Valley (northern Apennines, Italy). Hystrix 7:137-142

Miller J, Hobbs RJ (2002) Conservation where people live and work. Cons Biol 16:330-337

Naughton-Treves L, Mena JL, Treves A, Alvarez N, Radeloff VC (2003) Wildlife survival beyond park boundaries: the impact of slash-and- 
burn agriculture and hinting on mammals in Tambopata, Peru. Cons Biol 17:1106-1117

Olszewski JL (1986) The role of forest ecosystems in modifying local climate of the Białowieża Primeval Forest, as revealed by air temperature characteristics. Wydawnictwo PAN, Ossolineum, Wrocław [In Polish with English summary]

Padial JM, Avila E, Gil-Sanchez JM (2002) Feeding habits and overlap among red fox (Vulpes culpes) and stone marten (Martes foina) in two Mediterranean mountain habitats. Mamm Biol 67:137-146. doi:10.1078/1616-5047-00021

Pandolfi M, De Marinis AM, Petrov I (1996) Fruit as a winter feeding resource in the diet of Stone marten (Martes foina) in east-central Italy. Z Saugetierkunde 61:215-220

Pedrini P, Prigioni C, Volcan G (1995) Use of trophic resources and forest habitats by the genus Martes in Adamello - Brenta Park (central Italian Alps). Hystrix 7:127-135

Pianka ER (1973) The structure of lizard communities. Ann Rev Ecol Syst 4:53-74

Posillico M, Serafini R, Lovari S (1995) Activity patterns of the stone marten Martes foina Erxleben, 1777, in relation to some environmental factors. Hystrix 7:79-97

Posłuszny M, Pilot M, Goszczyński J, Gralak B (2007) Diet of sympatric pine marten (Martes martes) and stone marten (Martes foina) identified by genotyping of DNA from faeces. Ann Zool Fenn 44:269284

Pucek Z (1984) Klucz do oznaczania ssaków Polski. Państwowe Wydawnictwo Naukowe, Warszawa

Rodel HG, Stubbe M (2006) Shifts in food availability and associated shifts in space use and diet in stone marten. Lutra 49:67-72

Romanowski J, Lesiński G (1991) A note on the diet of stone marten in southeastern Romania. Acta Theriol 36:201-204

Ramankutty N, Foley JA (1999) Estimating historical changes in global land cover: Croplands from 1700 to 1992. Glob Biogeochem Cycles 13:997-1027. doi:10.1029/1999GB900046

Rondinini C, Boitani L (2002) Habitat use by beech martens in a fragmented landscape. Ecography 25:257-264. doi:10.1034/j. 1600-0587.2002.250301.x

Ruprecht AL, Buszko S (1985) Stone marten, Martes foina (Erxleben, 1777) in western part of the Białowieżą Primeval Forest. Przegląd Zoologiczny XXIX:105-108 [In Polish with English summary]

Sacchi O, Meriggi A (1995) Habitat requirements of the stone marten (Martes foina) on the Tyrrhenian slopes of the northern Apennines. Hystrix 7:99-104

Santos MJ, Miguel B, Santos-Reis M (2007) Trophic niche partitioning between two native and two exotic carnivores in SW Portugal. Web Ecol 7:53-62

Serafini P, Lovari S (1993) Food habits and trophic niche overlap of the red fox and the stone marten in a Mediterranean rural area. Acta Theriol 38:233-244

Shochat E, Warren PS, Faeth SH, McIntyre NE, Hope D (2006) From patterns to emerging processes in mechanistic urban ecology. Trends Ecol Evol 21:186-191. doi:10.1016/j.tree.2005.11.019
StatSoft I (2011) STATISTICA, ver. 10. Tulsa, OK

Teerink BJ (1991) Hair of West-European Mammals. Cambridge University Press, Cambridge, New York, Port Chester, Melbourne, Sydney

Thompson ID, Colgan PW (1987) Numerical responses of martens to a food shortage in northcentral Ontario. J Wildl Manag 51:824-835

Thompson ID, Colgan PW (1990) Prey choice by marten during a decline in prey abundance. Oecologia 83:443-451

Treves A, Karanth KU (2003) Human-carnivore conflict and perspectives on carnivore management worldlife. Cons Biol 17:1491-1499

Virgos E, Cabezas-Diaz S, Mangas JG, Lozano J (2010) Spatial distribution models in a frugivorous carnivore, the stone marten (Martes foina): is the fleshy-fruit availability a useful predictor? Anim Biol 60:423-436. doi:10.1163/157075610X523297

Vitousek PM, Mooney HA, Lubchenco J, Melillo JM (1997) Human domination of Earth's ecosystems. Science 277:494-499. doi:10. $1126 /$ science. 277.5325 .494

Wereszczuk A, Zalewski A (2015) Spatial niche segregation of sympatric stone marten and pine marten - avoidance of competition or selection of optimal habitat? PLoS One 10(10), e 0139852. doi:10.1371/ journal.pone. 0139852

Wijnhoven S, Van Der Velde G, Leuven RSEW, Smits AJM (2005) Flooding ecology of voles, mice and shrews: the importance of geomorphological and vegetational heterogeneity in river floodplains. Acta Theriol 50:453-472. doi:10.1007/ BF03192639

Zalewski A (2000) Factors affecting the duration of activity by pine martens (Martes martes) in the Białowieża National Park, Poland. J Zool 251:439-447. doi:10.1111/j.1469-7998.2000. tb00799.x

Zalewski A (2001) Seasonal and sexual variation in diel activity rhythms of pine martenMartes martes in the Białowieża National Park (Poland). Acta Theriol 46:295-304. doi:10.1007/BF03192436

Zalewski A (2004) Geographical and seasonal variation in food habits and prey size of the European pine marten Martes martes. In: Harrison DJ, Fuller AK and Proulx G (eds.) Martens and fishers (Martes) in human-altered environments: an international perspective. Kluwer Academy Publishers, pp 77-98

Zalewski A, Jędrzejewski W, Jędrzejewska B (2004) Mobility and home range use by pine martens (Martes martes) in a Polish primeval forest. Ecoscience 11:113-122

Zalewski A, Jędrzejewski W (2006) Spatial organization and dynamics of the pine marten Martes martes population in Białowieża Forest (E Poland) compared with other European woodlands. Ecography 29: 31-43. doi:10.1111/j.2005.0906-7590.04313.x

Zalewski A (2007) Does size dimorphism reduce competition between sexes? The diet of male and female pine martens at local and wider geographical scales. Acta Theriol 52:237-250

Zub K, Jędrzejewska B, Jędrzejewski W, Bartoń KA (2012) Cyclic voles and shrews and non-cyclic mice in a marginal grassland within European temperate forest. Acta Theriol 57:205-216. doi:10.1007/ s13364-012-0072-2 